\title{
Spatially and Temporally Resolved Single-Cell Exocytosis Utilizing Individually Addressable Carbon Microelectrode Arrays
}

\author{
Bo Zhang ${ }^{\dagger}$, Kelly L. Adams ${ }^{\dagger}, \ddagger$, Sarah J. Luber ${ }^{\dagger}$, Daniel J. Eves ${ }^{\dagger}$, Michael L. Heien ${ }^{\dagger}$, and \\ Andrew G. Ewing ${ }^{*}, \dagger, \ddagger$ \\ Department of Chemistry, 104 Chemistry Research Building, The Pennsylvania State University, \\ University Park, Pennsylvania 16802, and Department of Chemistry, Göteborg University, \\ Kemivägen 10, SE-41296, Göteborg, Sweden
}

\begin{abstract}
We report the fabrication and characterization of carbon microelectrode arrays (MEAs) and their application to spatially and temporally resolve neurotransmitter release from single pheochromocytoma (PC12) cells. The carbon MEAs are composed of individually addressable 2.5$\mu \mathrm{m}$-radius microdisks embedded in glass. The fabrication involves pulling a multibarrel glass capillary containing a single carbon fiber in each barrel into a sharp tip, followed by beveling the electrode tip to form an array $(10-20 \mu \mathrm{m})$ of carbon microdisks. This simple fabrication procedure eliminates the need for complicated wiring of the independent electrodes, thus allowing preparation of high-density individually addressable microelectrodes. The carbon MEAs have been characterized using scanning electron microscopy, steady-state and fast-scan voltammetry, and numerical simulations. Amperometric results show that subcellular heterogeneity in single-cell exocytosis can be electrochemically detected with MEAs. These ultrasmall electrochemical probes are suitable for detecting fast chemical events in tight spaces, as well as for developing multifunctional electrochemical microsensors.
\end{abstract}

Neuronal communication is facilitated by the release of chemical messengers, often via a process called exocytosis. In exocytosis, intracellular vesicles containing neurotransmitters fuse with the cell membrane to release their contents into the extracellular space. ${ }^{1}$ Such vesiclefusion processes are known to be triggered by calcium ions and regulated by various membrane proteins (e.g., the soluble $\mathrm{N}$-ethylmaleimide-sensitive factor attachment protein receptor (SNARE) proteins). ${ }^{2}$

Electrochemical methods utilizing carbon-fiber microelectrodes have been extremely useful in the detection of easily oxidizable neurochemicals (e.g., dopamine, epinephrine, 5hydroxytryptamine, and histamine) from single cells. ${ }^{3,4}$ In a typical experiment, a carbon-fiber microdisk electrode is placed flush with the cell surface. The electrode potential is held constant (in amperometry) or scanned (in cyclic voltammetry) with respect to a reference electrode placed in the extracellular media. Quantitative and qualitative information about neurotransmission can be obtained from $i-t$ and $i-V$ responses. ${ }^{5}$ Experiments using a single

\footnotetext{
* To whom correspondence should be addressed. E-mail: andrew.ewing@ chem.gu.se.

$\dagger$ The Pennsylvania State University.

Föteborg University.
}

Illustration showing the insertion of single 5- $\mu \mathrm{m}$ carbon fibers in a multibarrel glass capillary, schematic of the electrochemical cell and the electrode used in numerical simulations, comparison of the experimental and the simulated data of the normalized steady-state limiting current at a two-fiber MEA, and steady-state voltammetric response of a three-fiber MEA. This material is available free of charge via the Internet at http://pubs.acs.org. 
carbon-fiber microelectrode provide valuable information such as chemical identity, amount of the neurotransmitter released, event frequency, and kinetic information relating to fusion pore opening. ${ }^{6}$ However, information concerning spatial heterogeneity of exocytotic events is difficult to obtain. Such information can be useful in understanding the molecular mechanisms and the chemical basis for regulation of neural secretion. By comparing the number of exocytotic events recorded simultaneously at two $1-\mu \mathrm{m}$ carbon microelectrodes placed on the same chromaffin cell, Wightman and co-workers discovered the presence of "hot spots" (where exocytosis was more frequent) and "cold spots" (where exocytosis was less frequent) on the same cell. ${ }^{7}$ Due to the difficulties in micromanipulation, it is extremely challenging to record from more than one microelectrode concurrently at a single cell. Simultaneously monitoring exocytotic events from multiple sub-cellular sites of a single cell would be greatly facilitated by microelectrode arrays (MEAs).

MEAs have been intensively studied in the past two decades, not only by the chemical community 8 but also by scientists probing neuronal communication in brain tissue slices 9 , 10 and in cultured networks of neuronal cells. ${ }^{11-13}$ MEAs have also been used in a variety of studies, including drug discovery, ${ }^{14,15}$ diffusion of chemical species in solid electrolyte and electrolyte solutions, ${ }^{16}$ and chemical and biochemical sensing. ${ }^{17-22}$ Microfabrication technologies have been widely applied in the fabrication of MEAs. ${ }^{23-32}$ Alternative techniques have also been developed. Examples include chemical or electrochemical deposition of metals in nanoporous or microporous materials (polymers 33,34 or glass ${ }^{35,36}$ ), chemical etching 37 or micropatterning 38 on metal-supported self-assembled monolayers (SAMs), and chemically attaching metal nanoparticles onto SAMs at the electrode surface. ${ }^{39}$

Individually addressable MEAs offer many advantages compared to their counter parts, such as high spatial resolution, the possibility of sensing multiple analytes using different microelectrodes in the array, and probing signal transmission in a network of biological cells. The Michael group reported a method of constructing two or four individually addressable carbon ultramicroelectrodes (radii $\sim 1 \mu \mathrm{m}$ ) separated by a distance of $\sim 15 \mu \mathrm{m} .{ }^{40}$ Each carbon fiber was etched into a sharp tip and then electrically isolated by coating the tip with poly (allylphenol). These electrochemical arrays were used to simultaneously probe dopamine release in the brain at multiple sites. In a recent report, Lindau and co-workers microfabricated an array of four gold disk electrodes on a chip and recorded exocytotic events simultaneously from these MEAs positioned under a single chromaffin cell. ${ }^{41}$ However, due to the patterning of the microelectrodes and relative size of the array compared to the cell, a large fraction of the cell membrane was not directly exposed to the electrode surfaces.

In this paper, we present the fabrication and characterization of micrometer-sized electrochemical probes containing closely packed arrays of carbon microdisk electrodes. The MEAs have compatible sizes to individual neuronal cells $(10-20 \mu \mathrm{m})$. The fabrication method eliminates the need for complicated wiring, allowing several microelectrodes to fit in a small area. Steady-state voltammetry and numerical simulations have been compared to study the overlap of steady-state diffusive flux between adjacent microelectrodes and its effect on the independence of each microelectrode. We also describe differential electrochemical detection of exocytosis on single PC12 cells using an array of seven tightly packed carbon microelectrodes.

\section{EXPERIMENTAL SECTION}

\section{Chemicals}

$\mathrm{KCl}$ (99.9\% Aldrich) and ferrocenemethanol $\left(\mathrm{FcCH}_{2}-\mathrm{OH}, 100 \%\right.$, Aldrich) were used as received. All solutions were made using $18 \mathrm{M} \Omega \cdot \mathrm{cm}$ water from a Millipore purification system. 


\section{Fabrication of Carbon MEAs}

A single 5- $\mu \mathrm{m}$-diameter carbon fiber (Amoco, Greenville, $\mathrm{SC}$ ) was initially inserted into each barrel of a multibarrel glass capillary (2B150F-4, 3B120F-4, 7B100F-4, World Precision Instruments), as illustrated in Figure SI1 (Supporting Information) to create electrodes of two, three, and seven barrels (Figure 1). Multiple 12-cm-long pieces of carbon fiber were isolated from a bundle and immobilized using tape. A home-pulled thin glass capillary ( $\sim 0.4-\mathrm{mm}$ o.d., $\sim 30$-cm long) connected to an in-house vacuum was used to pull a single carbon fiber into each barrel. The thin vacuum glass was preinserted into one barrel of the multibarrel glass capillary. A single carbon fiber was then aspirated into the thin glass capillary. The vacuum capillary was then pulled out from the multibarrel glass leaving the fiber in the large capillary. The above step was repeated until each barrel was filled with a single carbon fiber. The multibarrel glass capillary was then pulled using a regular glass capillary puller (P-97, Sutter Instruments) to form two microtips. The pulled electrode tip was visually inspected under an optical microscope to ensure the fibers were uniform inside the pulled glass tip. To produce a good seal between the glass and the fiber, the pulled electrode tip was dipped into a freshly prepared epoxy (Epo-Tek, Epoxy Technology) for $\sim 5 \mathrm{~min}$ and cured in an oven $\left(100^{\circ} \mathrm{C}\right)$ for $>24 \mathrm{~h}$. The electrode tip was cut and polished at an angle of $\sim 60^{\circ}$ on a microelectrode beveller (BV-10, Sutter Instruments). Each barrel was then back-filled with silver paint (Dupont). Electrical connection was made using a tungsten rod placed in each barrel. Epoxy was applied to secure the tungsten rods.

The number and the arrangement of the microelectrodes included in the array are preselected by using different multibarrel glass capillaries. We used two, three, and seven-barrel glass capillaries. The MEAs fabricated in the present research contain exclusively 5- $\mu \mathrm{m}$-diameter carbon fibers. The distance between different electrodes is an important parameter in the response of MEAs. ${ }^{42-44}$ Due to the conical shape and tapered tip of the pulled electrode, this geometric parameter can be controlled in the polishing of the electrode. The more electrode material removed by polishing, the larger the interelectrode distance will be. We have been able to obtain MEAs having interelectrode distances (center to center) from as small as $\sim 6$ $\mu \mathrm{m}$ to as large as $100 \mu \mathrm{m}$. Insulation is still maintained even when adjacent fibers are separated by submicrometer-thick glass due to the high resistivity of glass $\left(>10^{14} \Omega \cdot \mathrm{m}\right.$ for borosilicate glass $^{45}$ ).

\section{Electrochemical Apparatus}

A one-compartment, two-electrode cell was employed with the cell and preamplifier in a homebuilt Faraday cage. $\mathrm{A} \mathrm{Ag} / \mathrm{AgCl}$ electrode was used as the reference/auxiliary electrode. Four bipotentiostats (EI-400, Ensman) were used to perform the multichannel voltammetric measurements. The triangle waveform was generated from one potentiostat and was output to the other three bipotentiostats. The bipotentiostats were interfaced to a PC computer through a multichannel data acquisition system (Digidata 1440A, Molecular Devices). Voltammetric responses were plotted using Origin 7.5 (OriginLab). Electrochemical recordings on single PC12 cells were made on an inverted microscope (CK30, Olympus) placed in a Faraday cage. A glass micropipet containing high $\mathrm{K}^{+}(100 \mathrm{mM})$ solution was positioned $\sim 100 \mu \mathrm{m}$ away to stimulate cell secretion. Each stimulus was applied for $5 \mathrm{~s}$ every $45 \mathrm{~s}$ at $30 \mathrm{psi}$ using a Femtojet (Eppendorf). A constant potential $(800 \mathrm{mV})$ was applied to each carbon microdisk with respect to a single $\mathrm{Ag} / \mathrm{AgCl}$ reference electrode placed in the cell bathing solution. Other experimental details were performed as previously described. ${ }^{46}$

\section{Scanning Electron Microscopy (SEM)}

SEM images of the carbon-fiber MEAs were obtained using a FEI Quanta 3D 200 FIB/SEM at the Penn State nanofabrication facilities. 


\section{Finite-Element Simulations}

The steady-state voltammetric response of a double-fiber-array microelectrode was simulated using Comsol Multiphysics 3.2 software (Comsol, Inc.) on a Dell PC (3GHz CPU, 2GB Memory).

\section{RESULTS AND DISCUSSION}

\section{Surface and Size Characterization by SEM}

Carbon MEAs have been characterized using SEM. Figure 2 shows typical SEM images of MEAs containing two, three, and seven microdisks, respectively. The electrodes are structurally well defined, and the overall diameters of the three-fiber and seven-fiber MEAs are between 15 and $20 \mu \mathrm{m}$, respectively. The $2.5-\mu \mathrm{m}$-radius carbon disks are tightly packed together and surrounded by a thin layer of glass $(\sim 1-2 \mu \mathrm{m})$.

\section{Steady-State Voltammetric Response of the Two-Fiber MEAs}

Figure 3 shows the steady-state voltammetric response of a two-fiber MEA at $10 \mathrm{mV} / \mathrm{s}$ in an aqueous solution containing $1 \mathrm{mM} \mathrm{FcCH}_{2} \mathrm{OH}$ and $0.2 \mathrm{M} \mathrm{KCl}$. The interelectrode distance, $d$, is $\sim 6.5 \mu \mathrm{m}$ in this case. Traces a and $\mathrm{b}$ in Figure 3 display the voltammetric response of $E_{\mathrm{a}}$ and $E_{\mathrm{b}}$ when the other is open circuited, respectively. Figure $3 \mathrm{c}$ shows the steady-state voltammetric response when $E_{\mathrm{a}}$ and $E_{\mathrm{b}}$ are connected and voltammetry measured at both electrodes collectively.

For a disk-shape microelectrode embedded in an infinitely thick insulating material, the steadystate limiting current, $i_{\mathrm{d}}$, is described using the following equation, 47

$$
i_{\mathrm{d}}=4 n F D C^{*} a
$$

where $n$ is the number of electrons transferred per molecule, $F$ is Faraday's constant, $D$ is the diffusion coefficient, and $C^{*}$ and $a$ are the bulk concentration of the redox molecule and the radius of the microelectrode, respectively. In the case of carbon MEAs, the thickness of the insulating glass is small compared to the radii of the carbon microdisks. Thus, the measured steady-state limiting current is in fact larger than what is predicted using eq 1 . The predicted limiting current, $i_{\mathrm{d}}$, using eq 1 , is $753 \mathrm{pA}$ on a $2.5-\mu \mathrm{m}$-radius disk microelectrode in $1 \mathrm{mM}$ $\mathrm{FcCH}_{2} \mathrm{OH}\left(D=7.8 \times 10^{-6} \mathrm{~cm}^{2} / \mathrm{s}\right) .{ }^{48}$ The actual measured limiting currents are 1100 and 1020 $\mathrm{pA}$ for $E_{\mathrm{a}}$ and $E_{\mathrm{b}}$, respectively, which are $\sim 46$ and $\sim 35 \%$ larger than the predicted value. The difference in limiting current is apparently due to the underestimated diffusive flux of redox molecule from the bulk to the electrode. This concept has been simulated for small electrodes of varied insulation thickness. ${ }^{49}$ In this perspective, the steady-state voltammetric response of a carbon microelectrode is better described by using the equation for a hemispherical microelectrode ${ }^{50}$

$$
i_{d}=2 \pi n F D C^{*} a
$$

where the only difference is a larger constant, $2 \pi$, as compared to 4 in eq 1 . The computed limiting current, $i_{\mathrm{d}}$, is $1180 \mathrm{pA}$ using eq 2 , in fair agreement with what is measured at each carbon microelectrode.

Figure $3 \mathrm{c}$ shows the overall steady-state voltammetric response of the two carbon fibers measured when they are connected. The limiting current in Figure $3 \mathrm{c}$ is in fact $\sim 15 \%$ smaller than the sum of the limiting currents individually measured at the two micro-electrodes. Experiments and numerical simulations have shown that the voltammetric response of a $2 \mathrm{D}$ 
microdisk electrode array is largely affected by its interelectrode distances: when microdisks are well separated, they behave like individual electrodes; when they are close to each other, they behave like a macroelectrode. ${ }^{42-44}$ In our case, there is clearly overlap of the depletion layers at the two electrodes.

The effects of $d$ on the steady-state voltammetric response of a two-fiber MEA have been studied by Baur and Motsegood by the use of both steady-state electrochemical measurements and numerical simulations. ${ }^{51}$ In the following section, we present a finite-element simulation of the distribution of diffusive flux at the electrodes to visualize the overlap of the diffusion layers.

\section{Finite-Element Simulation of the Steady-State Diffusive Flux at a Two-Fiber MEA}

The numerical simulation of diffusive flux was accomplished in 3D space using a steady-state diffusion model (using Comsol software Ver. 3.2, Comsol Inc.). ${ }^{52}$ In the simulation, the radii $(a=2.5 \mu \mathrm{m})$ and the length $(100 \mu \mathrm{m}, 40 \times$ larger than $a)$ of the microdisk electrodes were held constant and the interelectrode distance was varied. A 500- $\mu \mathrm{m}(200 \times$ lager than $a)$ cubic box was used as the electrochemical cell, in which the concentration of redox species at the surface of cubic box $(1 \mathrm{mM})$ and at the electrode surface $(0 \mathrm{mM})$ were held constant. For simplicity, the thickness of the insulation material surrounding and between the two microdisks was not considered; thus, the calculated current is likely to be slightly larger than what is obtained experimentally. However, this should not affect the analysis of the "cross talk" between the two microelectrodes significantly. A schematic drawing of the electrochemical cell and the electrodes is given in the Supporting Information, Figure SI2. The normalized steady-state current from the simulation is in good agreement with the experimental data (Figure SI3). Both the simulation and the experiment show that when $(d / a)$ is $\sim 5$, they behave independently.

The interelectrode distance required for isolation of responses can be qualitatively understood by use of a computer-simulated spatial distribution of steady-state flux of redox species. Figure 4 displays the simulated cross-sectional distribution of the steady-state flux of the redox molecules $\left(1 \mathrm{mM} \mathrm{FcCH}_{2} \mathrm{OH}, V_{\mathrm{app}}=0.5 \mathrm{~V}\right.$ vs Ag/AgCl$)$ near the electrode surface. The overlap of the flux of redox molecules from bulk solution to the two microdisks can be easily visualized when $d$ is small compared to the radius of the electrode (e.g., $d / a=2.4$ ), as shown in Figure 4A. It is smaller (but still noticeable) when $d / a$ is 4 , as shown in Figure 4B. However, when $d$ becomes even larger, as displayed in Figure 4C $(d / a=10)$ and D $(d / a=20)$, no significant overlap is observed in the simulated data. This is in agreement with the steady-state electrochemical responses of the two microelectrodes.

\section{Voltammetric Response of a Seven-Fiber MEA}

Steady-state and fast-scan voltammetry has been used to characterize a seven-carbon-fiber MEA. An optical microscopy image shows that the electrode has a total tip dimension of $\sim 20$ $\mu \mathrm{m}$, which indicates that the interelectrode distance in the array is $\sim 7 \mu \mathrm{m}$. As the diameter of each microdisk is $5 \mu \mathrm{m}$, the thickness of the glass between adjacent fibers is $\sim 2 \mu \mathrm{m}$. Figure $5 \mathrm{~A}$ - G shows the steady-state voltammetric response of each microelectrode (Figure 5 shows the relative position of each microelectrode in the array) measured simultaneously at $20 \mathrm{mV} / \mathrm{s}$ in $1 \mathrm{mM} \mathrm{FcCH}_{2} \mathrm{OH}$ and $0.2 \mathrm{M} \mathrm{KCl}$. The voltammetric response is well defined and has a sigmoidal shape at this scan rate. The steady-state limiting current at each microelectrode is approximately the same, except for $E_{\mathrm{g}}$ (Figure 5G). Close inspection of the voltammogram in Figure 5G indicates that the diffusion-limited steady-state current for the center electrode is $\sim 40 \%$ smaller than that observed for the edge electrodes (A-F). The limiting current for the surrounding electrodes is $\sim 610 \mathrm{pA}$, which is $48 \%$ smaller than what is predicted using eq 2 . This difference is apparently due to geometrically hindered diffusion combined with depletion of the analyte by the surrounding electrodes. This is more evident for the center electrode as 
the limiting current at this electrode is somewhat shielded by the collection of microelectrodes surrounding it.

Figure $6 \mathrm{~A}-\mathrm{G}$ shows the raw fast-scan voltammetric responses of each electrode in the same seven-fiber MEA at $300 \mathrm{~V} / \mathrm{s}$ in the same solution. On top of the capacitive charging current are two voltammetric peaks corresponding to oxidation and reduction of $\mathrm{FcCH}_{2} \mathrm{OH}$ and $\mathrm{FcCH}_{2} \mathrm{OH}^{+}$, respectively. The average double-layer charging current is $\sim 3 \mathrm{nA}$, which corresponds to a double-layer capacitance of $\sim 10 \mathrm{pF}$ at each electrode $\left(\sim 51 \mu \mathrm{F} / \mathrm{cm}^{2}\right)$. The peak currents at electrodes $E_{\mathrm{a}}-E_{\mathrm{g}}$ are approximately the same, $\sim 3 \mathrm{nA}$. No significant difference is found in the fast-scan voltammetric response of $E_{\mathrm{g}}$ (e.g., Figure $6 \mathrm{G}$ ), indicating that the depletion layer is small as the voltammetric response is due mainly to molecules adjacent to the electrode at this scan rate. ${ }^{53}$ These results demonstrate that the microelectrodes are individually addressable and behave ideally in voltammetric measurements.

Here we have used the MEA to carry our measurements of exocytosis at single cells. To measure exocytosis in single-cell experiments, a microdisk electrode is typically placed close to the cell membrane to detect released transmitter. Released transmitters are oxidized locally and free diffusion is minimized by the small electrode/cell separation.

\section{Amperometric Detection of Neurotransmitter Release from Single PC12 Cells: An Electrochemical Array Image}

Electrochemical recordings using carbon MEAs are expected to provide excellent temporal resolution and allow simultaneous examination of different membrane areas with subcellular resolution. We have used this ability to compare biofunctionality in terms of exocytosis. Figure 7A shows an optical micrograph of a carbon MEA placed on a single PC12 cell. A glass micropipette containing high $\mathrm{K}^{+}$solution $(100 \mathrm{mM})$ was positioned $\sim 100 \mu$ m away to stimulate secretion. Figure 7B displays a 16-min amperometric recording of exocytotic events at a single PC12 cell. Each current transient corresponds to the electrochemical oxidation of dopamine molecules secreted from a single intracellular vesicle.

Noticeable in Figure 7B is subcellular heterogeneity observed in single-cell exocytosis. For example, the area of cell membrane under $E_{\mathrm{f}}$ shows fewer events than the others during the first $8 \mathrm{~min}$ and appears to be a "cold spot". More interestingly, spots may be "hot" during a specific period, but then change to be "cold" (or vice versa) after another stimulus. Close inspection of the response from $E_{\mathrm{a}}$ shows there are fewer events detected after the second and the fifth stimuli than after the third and fourth. In addition, $E_{\mathrm{f}}$ and $E_{\mathrm{g}}$ clearly detected more events in the last $8 \mathrm{~min}$ than in the first. Thus, it appears that the array electrode format allows detection of localized membrane function in terms of exocytosis at a single cell.

The detection probability on each channel was compared from 16 different PC12 cells ( $n=8$ electrode arrays) to ensure the differences detected with each channel do not arise from systematic errors, such as electrode placement or response. The number of events at each channel was normalized to the total number of events at a cell before averaging. Figure 7C displays a comparison of the averaged value of normalized number of events for each channel recorded from 16 PC12 cells. From the averaged data, there are no significant differences among the channels $(P$ value $=0.35$, one-way ANOVA $)$, indicating that differences seen in the number of detected exocytotic events at a given cell reflect the subcellular spatial heterogeneity in the exocytosis process. 


\section{Resolving Concurrent Exocytotic Events in Single-Cell Amperometric Detection Using Multifiber MEAs}

Another issue that can be examined with array electrodes is the incidence of concurrent events on the same cell. When more than one event occurs simultaneously, it is challenging to resolve them using a single microelectrode. In the absence of spatial resolution, these events will overlap and result in a large, broad current spike. Simultaneous, parallel recordings using multiple microelectrodes allow these events to be resolved based on spatial identification. Figure 8 shows a 1-s amperometric recording on a single PC12 cell using a seven-fiber MEA. The red arrows indicate three different exocytotic events detected from $E_{\mathrm{b}}, E_{\mathrm{c}}$, and $E_{\mathrm{g}}$, respectively. The events are extremely similar temporally that with one electrode they would form a single large, broader current spike. Although rare, these overlapping events can be spatially resolved by our seven-fiber MEA. The multiple detection sites present allow the temporally synchronous release events present at different electrodes to be resolved.

\section{CONCLUSIONS}

We have fabricated carbon-fiber MEAs that are applicable for spatially probing chemical changes in tight spaces, such as studying exocytosis from different regions of single-cell surfaces. Electron microscopic characterization showed that these microsensor arrays were on the order of $20 \mu \mathrm{m}$ and were geometrically well defined. Finite-element simulation was applied to qualitatively study the "cross talk" in a two-fiber MEA. Steady-state and fast-scan voltammetric responses demonstrated that the MEAs have well-defined electrochemical behavior and each microelectrode can be individually addressed. A seven-fiber MEA was used for simultaneous electrochemical monitoring of exocytotic events from different surface regions of single PC12 cells. Subcellular heterogeneity in exocytosis was shown with 5- $\mu \mathrm{m}$ resolution. Concurrent exocytotic events under different micro-electrodes were also resolved using MEAs. These results show that carbon-fiber-based microelectrode arrays are suitable for electrochemical imaging of fast exocytotic events at single cells.

\section{Supplementary Material}

Refer to Web version on PubMed Central for supplementary material.

\section{ACKNOWLEDGMENT}

We thank Michael F. Santillo for his help in numerical simulations. This publication was supported by The Pennsylvania State University MRI Nano Fabrication Network and the NSF Cooperative Agreement 0335765, National Nanotechnology Infrastructure Network, with Cornell University. This work was supported by funding from the NIH. A.G.E. is supported by a Marie Curie Chair from the European Union 6th Framework.

\section{References}

1. Kandel, ER.; Schwartz, JH.; Jessell, TM. Principles of Neural Science. Vol. 4th ed.. McGraw Hill; New York: 2000.

2. Weber T, Zemelman BV, McNew JA, Westermann B, Gmachl M, Parlati F, Sollner TH, Rothman JF. Cell 1998;92:759. [PubMed: 9529252]

3. Wightman RM, Jankowski JA, Kennedy RT, Kawagoe KT, Schroeder TJ, Leszczyszyn DJ, Near JA, Diliberto EJ Jr. Viveros OH. Proc. Natl. Acad. Sci. U.S.A 1991;88:10754. [PubMed: 1961743]

4. Chen TK, Luo G, Ewing AG. Anal. Chem 1994;66:3031. [PubMed: 7978300]

5. Wightman RM. Science 2006;311:1570. [PubMed: 16543451]

6. Mosharov E, Sulzer D. Nat. Methods 2005;2:651. [PubMed: 16118635]

7. Schroeder TJ, Jankowski JA, Senyshyn J, Holz RW, Wightman RM. J. Biol. Chem 1994;269:17215. [PubMed: 8006030] 
8. Stefan RI, Staden JFV, Aboul-Ensin HY. Crit. Rev. Anal. Chem 1999;29:133.

9. Droge MH, Gross GW, Hightower MG, Czisny LE. J. Neurosci 1986;6:1583. [PubMed: 3711997]

10. Wilson, M. Multiple-Electrode Recordings of Neuronal Ensemble Activity.. In: Buzsaki, G., editor. Visualizing Large-Scale Patterns of Activity in the Brain: Optical and Electrical Signals. Society for Neuroscience; Atlanta, GA: 2006. p. 9-16.

11. Maher MP, Pine J, Wright J, Tai YC. J. Neurosci. Methods 1999;87:45. [PubMed: 10065993]

12. Suzuki I, Sugio Y, Jimbo Y, Yasuda K. Lab Chip 2005;5:241. [PubMed: 15726199]

13. Arcibal, I.; Santillo, MJ.; Ewing, AG. Unpublished results.

14. Yeung CK, Sommerhage F, Wrobel G, Offenhausser A, Chan M, Ingebrandt S. Anal. Bioanal. Chem 2007;387:2673. [PubMed: 17318515]

15. Stett A, Egert U, Guenther E, Hofmann F, Meyer T, Nisch W, Haemmerle H. Anal. Bioanal. Chem 2003;377:486. [PubMed: 12923608]

16. a Licht S, Cammarata V, Wrighton MS. Science 1989;243:1176. [PubMed: 17799898] b Cammarata V, Talham DR, Crooks RM, Wrighton MS. J. Phys. Chem 1990;94:2680.

17. a Gavin PF, Ewing AG. J. Am. Chem. Soc 1996;118:8932. b Gavin PF, Ewing AG. Anal. Chem 1997;69:3838.

18. Belmont-Hebert C, Tercier ML, Buffle J, Fiaccabrino CC, De Rooij NF, Koudelka-Hep M. Anal. Chem 1998;70:2949.

19. Feeney R, Kounaves SP. Anal. Chem 2000;72:2222. [PubMed: 10845367]

20. Wang J, Chen Q. Anal. Chem 1994;66:1007.

21. Niwa O, Xu Y, Halsall HB, Heineman WR. Anal. Chem 1993;65:1559. [PubMed: 8328672]

22. Fan Y, Chen X, Trigg AD, Tung CH, Kong J, Gao Z. J. Am. Chem. Soc 2007;129:5437. [PubMed: 17411036]

23. Lanyon YH, Arrigan DWM. Sens. Actuators, B 2007;121:341.

24. Sandison ME, Cooper JM. Lab Chip 2006;6:1020. [PubMed: 16874372]

25. a Nolan MA, Kounaves SP. Anal. Chem 1999;71:3567. b Feeney R, Kounaves SP. Electroanalysis 2000;12:677.

26. a Nagale MP, Fritsch I. Anal. Chem 1998;70:2902. b Nagale MP, Fritsch I. Anal. Chem 1998;70:2908. 27. Sandison ME, Anicet N, Glidle A, Cooper JM. Anal. Chem 2002;74:5717. [PubMed: 12463354]

28. Li J, Ng HT, Cassell A, Fan W, Chen H, Ye Q, Koehne J, Han J, Meyyappan M. Nano Lett 2003;3:597. 29. Sreenivas G, Ang SS, Fritsch I, Brown WD, Greg AG, Woodward DJ. Anal. Chem 1996;68:1858. 30. Wang K, Fishman HA, Dai HJ, Harris JS. Nano Lett 2006;6:2043. [PubMed: 16968023]

31. Li X, Zhou Y, Sutherland TC, Baker B, Lee JS, Kraatz HB. Anal. Chem 2005;77:5766. [PubMed: 16131094]

32. Zoski CG, Yang N, He P, Berdondini L, Koudelka-Hep M. Anal. Chem 2007;79:1474. [PubMed: 17297946] b Zoski CG, Simjee N, Guenat O, Koudelka-Hep M. Anal. Chem 2004;76:62.

33. a Menon VP, Martin CR. Anal. Chem 1995;67:1920. b Ugo P, Moretto LM, Bellomi S, Menon VP, Martin CR. Anal. Chem 1996;68:4160. c Martin CR. Science 1994;266:1961. [PubMed: 17836514] d Cepak VM, Hulteen JC, Che G, Jirage KB, Lakshmi BB, Fisher ER, Martin CR, Yoneyhama H. Chem. Mater 1997;9:1065.

34. Krishnamoorthy K, Zoski CG. Anal. Chem 2005;77:5068. [PubMed: 16053324]

35. Merritt CD, Justus BL. Chem. Mater 2003;15:2520.

36. Szunerits S, Walt DR. Anal. Chem 2002;74:1718. [PubMed: 12033265]

37. a Baker WS, Crooks RM. J. Phys. Chem. B 1998;102:10041. b Crooks RM, Ricco AJ. Acc. Chem. Res 1998;31:219.

38. He HX, Li QG, Zhou ZY, Zhang H, Li SFY, Liu ZF. Langmuir 2000;16:9683.

39. Cheng W, Dong S, Wang E. Anal. Chem 2002;74:3599. [PubMed: 12175142]

40. Dressman SF, Peters JL, Michael AC. J. Neuronsci. Methods 2002;119:75.

41. Hafez I, Kisler K, Berberian K, Dernick G, Valero V, Yong MG, Craighead HG, Lindau M. Proc. Natl. Acad. Sci. U.S.A 2005;102:13879. [PubMed: 16172395]

42. Sandison ME, Anicet N, Glidle A, Cooper JM. Anal. Chem 2002;74:5717. [PubMed: 12463354] 
43. a Lee HJ, Beriet C, Ferrigno R, Girault HH. J. Electroanal. Chem 2001;502:138. b Beriet C, Ferrigno R, Girault HH. J. Electroanal. Chem 2000;486:56.

44. a Morf WE. Anal. Chim. Acta 1996;330:139. b Morf WE. Anal. Chim. Acta 1997;341:121. c Morf WE, Rooij NF. Sensors Actuators, B 1997;44:538.

45. Harper, CA., editor. Handbook of Ceramics Glasses, and Diamonds. McGraw-Hill; New York: 2001.

46. Sombers LA, Hanchar HJ, Colliver TL, Wittenberg N, Cans A-S, Arbault S, Amatore C, Ewing AG. J. Neurosci 2004;24:303. [PubMed: 14724228]

47. Saito Y. Rev. Polarogr. (Jpn.) 1968;15:177.

48. Miao W, Ding Z, Bard AJ. J. Phys. Chem. B 2002;106:1392.

49. Shoup D, Szabo A. J. Electroanal. Chem 1984;160:27.

50. Bard, AJ.; Faulkner, LR. Electrochemical Methods. Vol. 2nd ed.. John Wiley \& Sons; New York: 2001.

51. Baur JE, Motsegood PN. J. Electroanal. Chem 2004;572:29.

52. Zhang B, Zhang Y, White HS. Anal. Chem 2004;76:6229. [PubMed: 15516113]

53. The distance that the redox molecule diffuses, $\delta=\left(2 D t_{\text {expt }}\right)^{0.5}$, at the time of the voltammetric experiment $\left(t_{\text {expt }}=R T / v F\right)$, is $\sim 0.36 \mu \mathrm{m}$. 

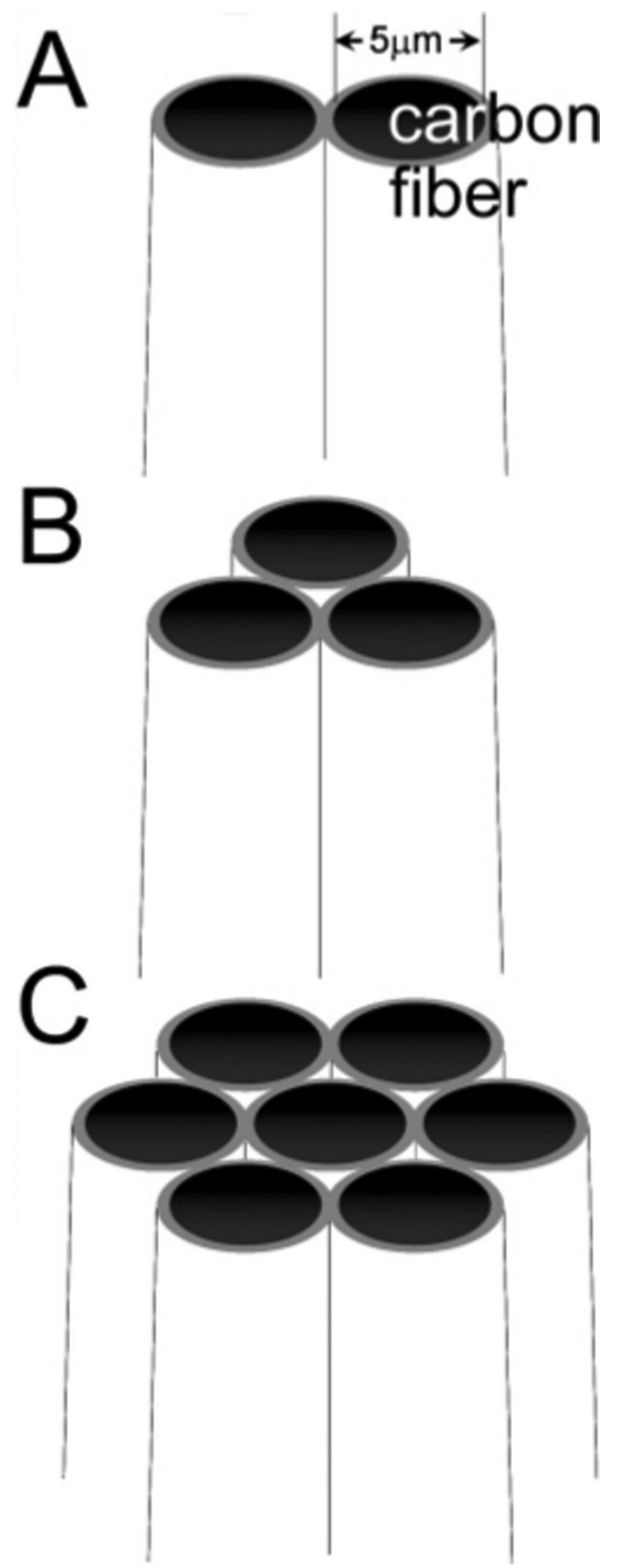

Figure 1.

Schematic drawing of carbon fiber MEAs containing two (A), three (B), and seven (C) microdisks. 


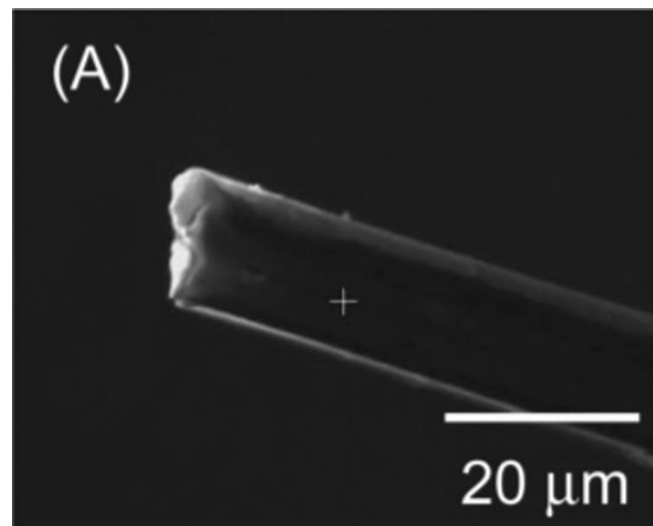

\section{(B)}

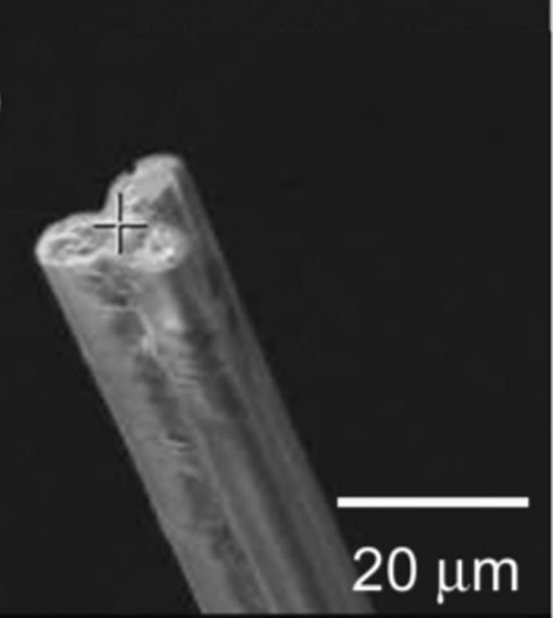

\section{(C)}

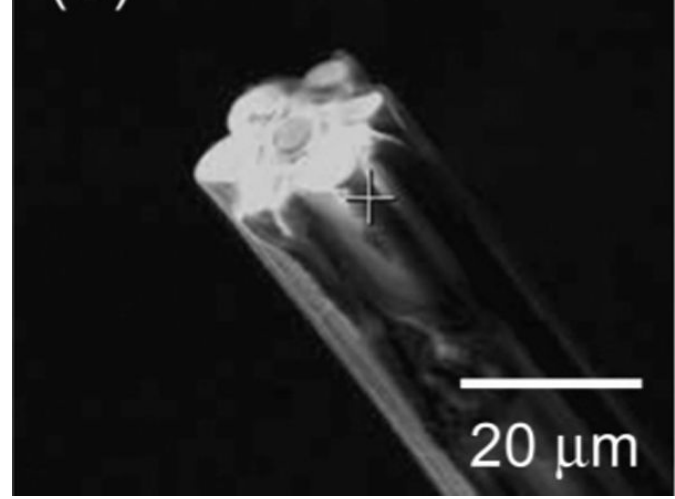

Figure 2.

Scanning electron microscopy of carbon fiber MEAs having two (A), three (B), and seven (C) microdisks. 


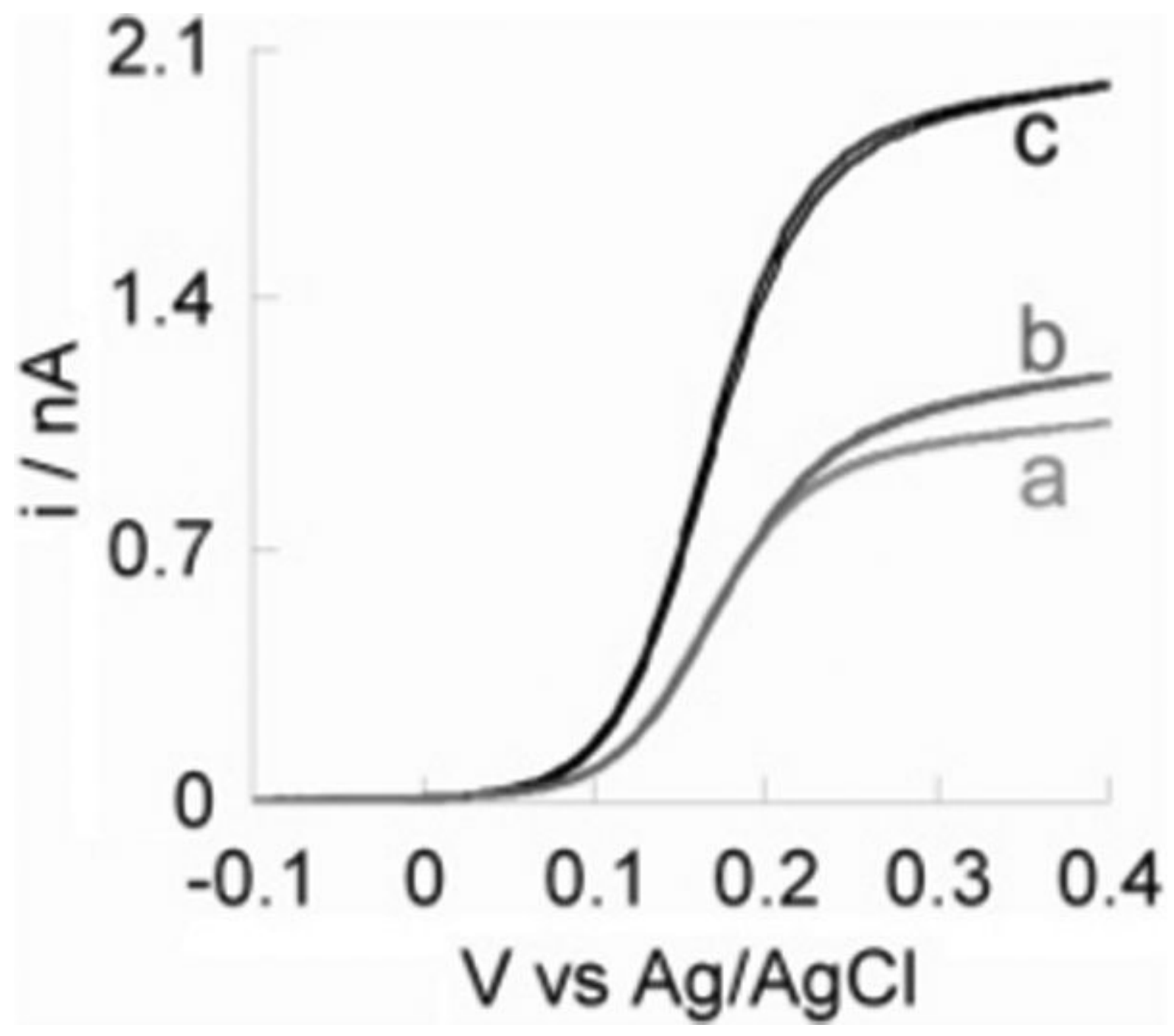

Figure 3.

Steady-state voltammetric response of a two-fiber MEA in $1 \mathrm{mM} \mathrm{FcCH}_{2} \mathrm{OH}$ containing $0.2 \mathrm{M}$ $\mathrm{KCl}$ at a scan rate of $10 \mathrm{mV} / \mathrm{s}$; (a) the response of microelectrode a alone, (b) the response of microelectrode $\mathrm{b}$ alone, and (c) the response of both microelectrodes operated and connected together. 


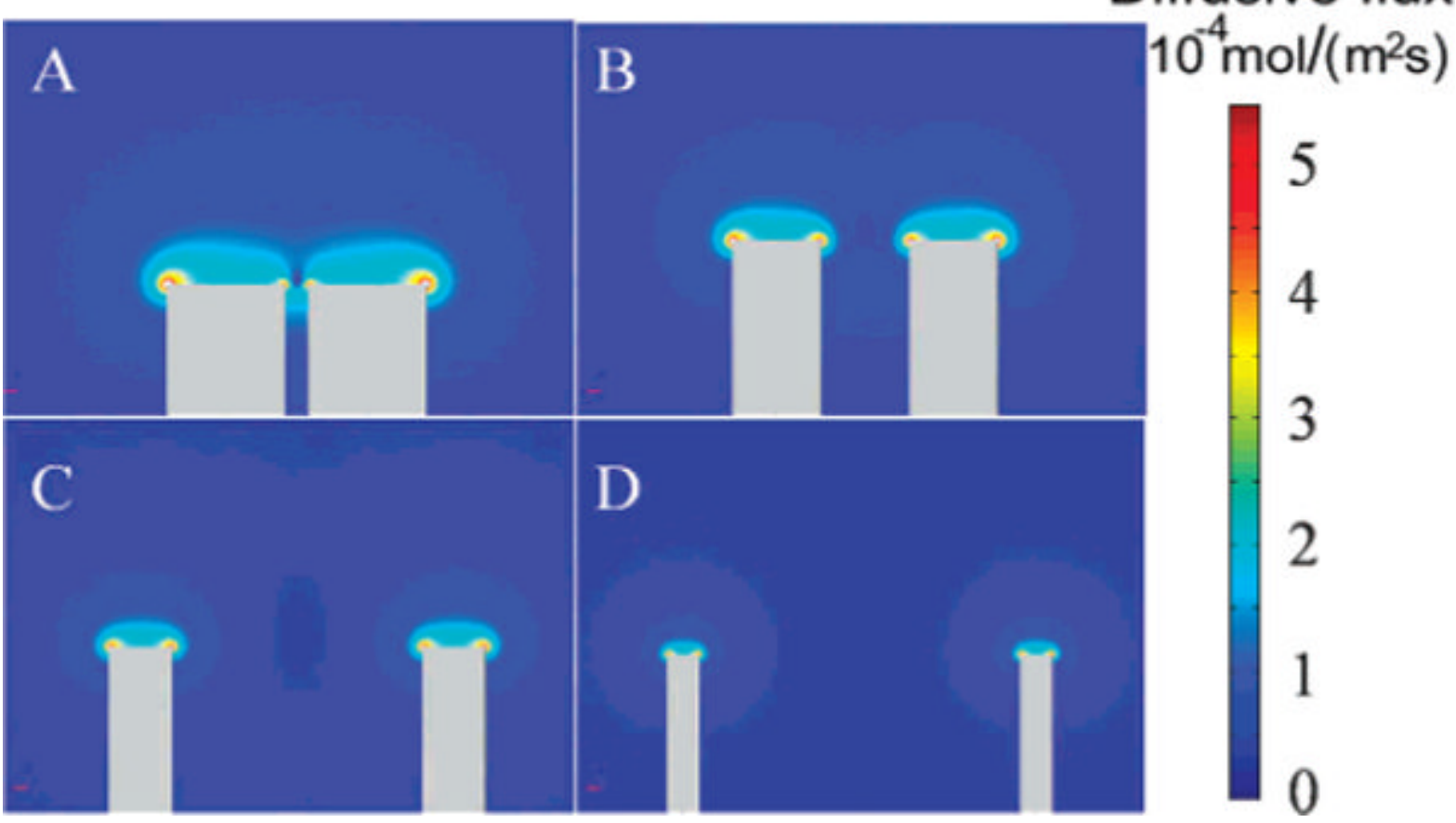

Figure 4.

Simulated distribution of steady-state diffusive flux at the cross section of a 5- $\mu \mathrm{m}$ two-fiber MEA as a function of the interelectrode distance. The d/a are (A) 2.4, (B) 4, (C) 10, and (D) 20 , respectively. 


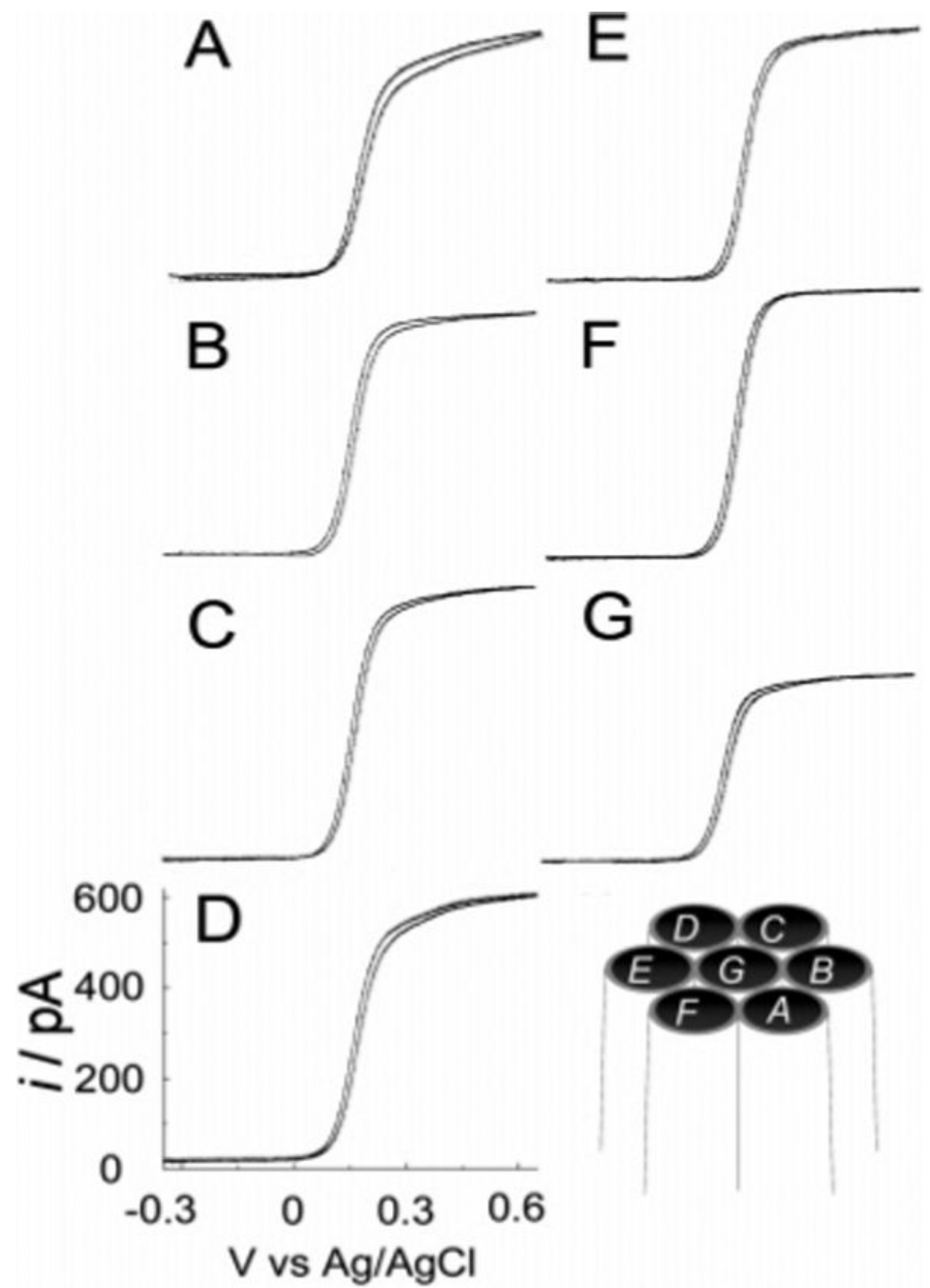

Figure 5.

Steady-state voltammetric response at $20 \mathrm{mV} / \mathrm{s}$ of a seven-fiber MEA in $1 \mathrm{mM} \mathrm{FcCH}_{2} \mathrm{OH}$ and $0.2 \mathrm{M} \mathrm{KCl}$. (A) - $(\mathrm{G})$ are the voltammetric response of individual microelectrodes $\mathrm{A}-\mathrm{G}$ as shown in the schematic of the microelectrode assemble shows in the bottom right. 

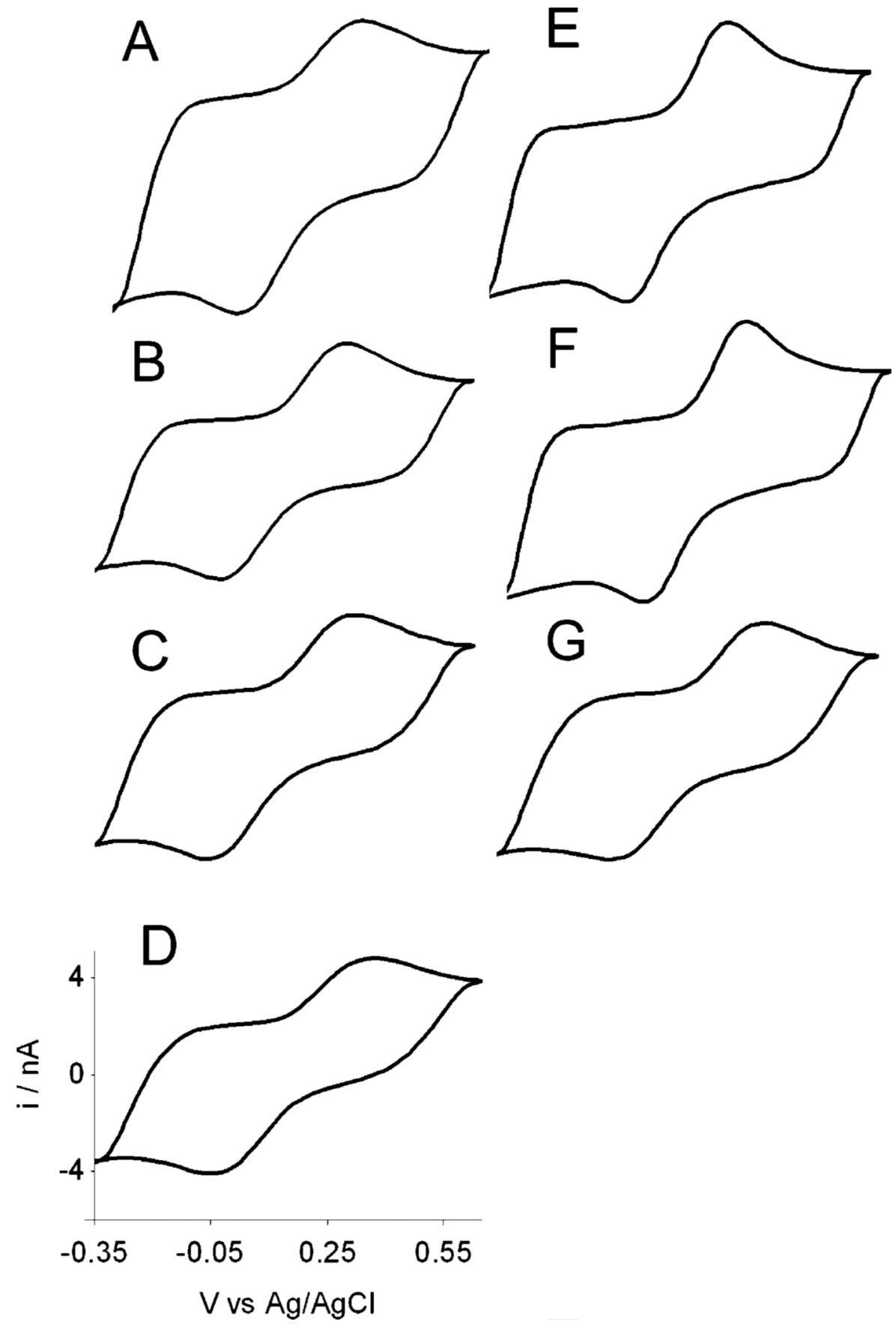

Figure 6.

Fast-scan voltammetric response $(300 \mathrm{~V} / \mathrm{s})$ of the same seven-fiber $\mathrm{MEA}$ in $1 \mathrm{mM} \mathrm{FcCH} \mathrm{OH}_{2}$ and $0.2 \mathrm{M} \mathrm{KCl}$. (A) - $(\mathrm{G})$ are the voltammetric response of individual microelectrodes $\mathrm{A}-\mathrm{G}$ (as seen in Figure 5). 

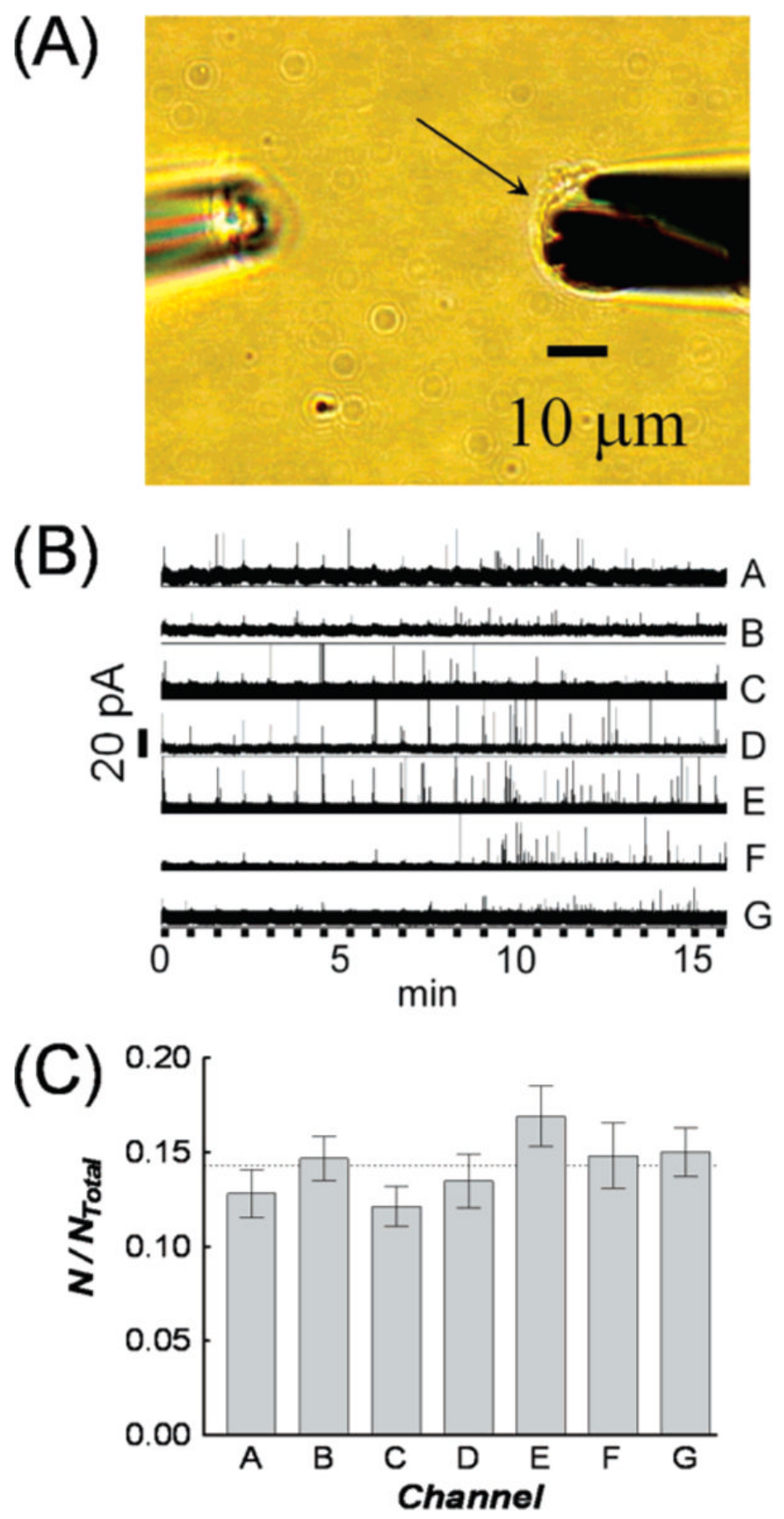

Figure 7.

(A) Optical image showing a microelectrode array positioned over a single PC12 cell (right) and a stimulation pipet (left). The cell is denoted with an arrow. (B) Amperometric traces of exocytotic release from a PC12 cell recorded using a microelectrode array. Thick black lines along the time axis indicate exposure to high potassium stimuli $(100 \mathrm{mM}, 5$-s pulse every 45 s). (C) The average value of normalized number of exocytotic events recorded with each electrode in the array. Eight different microelectrode arrays were use to examine 16 PC12 cells. Error bars are (S.E.M. 

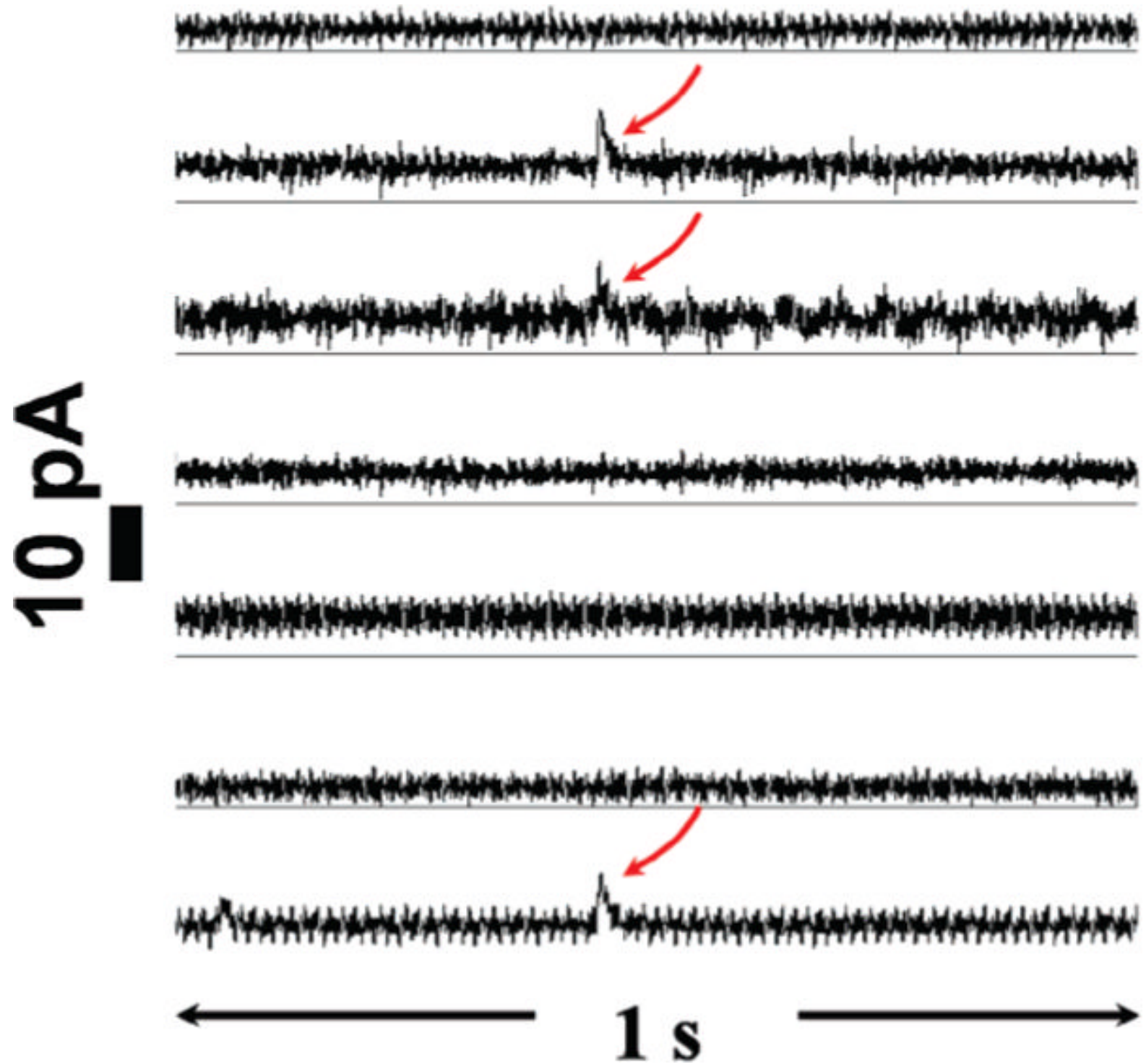

Figure 8.

A 1-s time period of an exocytotic response of a PC12 cell after potassium stimulation showing simultaneous detection of concurrent events at different locations on the same cell. Red arrows indicate these events. 